1. MBBS, MCE (AUS) FECSM Embryologist \& CEO LIFE

2. MBBS, FCPS, DIP Endoscopy (France)

Consultant-Endoscopic Surgeon \& Gynecologist, HLH \&LIFE

3. Masters of Physiology

Embryologist

LIFE, Hameed Latif Hospital Lahore.

4. M.Sc. Medical Lab Technician Embryologist

LIFE, Hameed Latif Hospital Lahore.

5. M.Sc. (Biostatistics) Assistant \& Biostatistician

6. MBBS, MPH, M.PHIL (Biostatistics)

Biostatistician \& Research Coordinator Life Pakistan

Correspondence Address: Dr. Abdul Rahman Khawaja MBBS, MPH, M.PHIL (Biostatistics) Biostatistician \& Research Coordinator Life Pakistan arkhaja@gmail.com

Article received on: 21/01/2016 Accepted for publication: 29/03/2016 Received after proof reading: 04/05/2016

\section{SEMEN PARAMETERS; \\ A DESCRIPTIVE OBSERVATIONAL STUDY ON SUB-FERTILE MALES PRESENTING AT A PRIVATE ASSISTED REPRODUCTION CLINIC IN LAHORE PAKISTAN.}

\section{Dr. Haroon Latif Khan', Prof. Dr. Yousaf Latif Khan², Irfan Mehfooz ${ }^{3}$, Muhammad Burhan ${ }^{4}$, Saba Sardar ${ }^{5}$, Dr. Abdul Rahman Khawaja ${ }^{6}$}

ABSTRACT: Semen is a pale whitish fluid secreted by male during ejaculation and contains spermatozoa which are male gametes essential of fertilizing the oocytes which are female gametes. In a quest to evaluate male's fertility potential semen is analyzed to look into some of its characteristics and of the sperms contained within the semen analyzed. Method of collection influences the results of Semen analysis as does the technique of analysis. Spermatozoa are examined for number (count), shape (morphology) and movement (motility) in order to assess their quality. Non sperm cells, volume, Fructose level, pH, liquefaction are also checked as a part of routine analysis. Objectives: To describe the pattern of semen parameters in subfertile males. To look into frequency and distribution of abnormal semen parameters in a group of Pakistani males in Lahore. Methods: In this Retrospective, cross sectional, observational study all males undergoing for evaluation and treatment for sub-fertility at a private Assisted Reproductive Technology clinic in Lahore, Pakistan were included. Approval of the IRB was sought and data collection instrument was a specially designed Performa which was validated by the biostatistician of LIFE research cell. Data was extracted from the files of LIFE (Lahore Institute of Fertility and Endocrinology) and entered in SPSS version 15. Sampling technique was non-probability, consecutive. Semen analysis was done by methods defined by the WHO (World Health Organization). Results: Of total patient $(n=679) 92.2 \%(626)$ males passed sample at LIFE (Lahore institute of fertility and endocrinology) and (7.8\%) 53 brought sample from home. Of the males who passed sample at LIFE (78.8\%) 535 collected semen by masturbation, (11.9\%) 81 by coitus; the source of sample of $(9.3 \%) 63$ males was not known. As $2-6 \mathrm{ml}$ semen was consider to be normal by WHO criteria, (80.6\%) 547 males were in normal range (14.1\%) 96 found to be less than $2-6 \mathrm{ml}$ and $(5.3 \%) 36$ found to be more than normal range. According to WHO criteria 15 million/ml count is said to be normal, in our research (82.0\%) 557 were found to be normal, in (2.9\%) 20 count was found to be less than 15 million/ml and in $(5.9 \%) 40$ count was less than 1 million/ml. In (9.1\%) 62 counts was found to be abnormally low. In this research (66.1\%) 449 had normal sperm motility, (21.8\%) 148 had less than $40 \%$ and abnormally low sperm motility was found in (12.1\%) 82 males. Conclusion: The results of the single semen analysis are of limited utility and no decision should be taken on the bases of these results in term of diagnosis and treatment strategies.

Key words: $\quad$ Semen analysis, subfertility, count, morphology, motility

Article Citation: Khan HL, Khan YL, Mehfooz I, Burhan M, Sardar S, Khawaja AR. Semen parameters; a descriptive observational study on sub-fertile males presenting at a private assisted reproduction clinic in Lahore Pakistan. Professional Med J 2016;23(5):589-596. DOI: 10.17957/TPMJ/16.3257

\section{INTRODUCTION}

Semen is a pale whitish fluid secreted by male during ejaculation and contains spermatozoa which are male gametes essential for fertilizing the oocytes which are female gametes. ${ }^{1}$ In a quest to evaluate male's fertility potential semen is analyzed to look into some of its characteristics and of the sperms contained within the semen analyzed. ${ }^{2,3}$
Method of collection influences the results of Semen analysis as does the technique of analysis. ${ }^{1}$ The results of semen analysis not only point towards the diagnosis but also helps in deciding about the interventions to be planned..$^{4,5}$ In order to assess their quality spermatozoa are examined for number (count), shape (morphology) and movement (motility). ${ }^{6}$ Non sperm cells, volume, Fructose level, $\mathrm{pH}$, liquefaction are also checked as a part of routine analysis. The values of semen 
analysis's results are compared with WHO reference values.

Sperms are stored in the lower portion of the epididymis before they pass through the ejaculatory ducts to reach the seminal vesicle. ${ }^{7}$ Fluids from this simple tubular gland are added to it and so are the secretions from the prostate and the bulbourethral glands. ${ }^{8}$ Composition of seminal fluid is complex and consist of various organic and inorganic components. Transport of spermatozoa through the female reproductive tract is essential to achieve fertilization the chances of which are maximized if intercourse occurs a few days prior to ovulation. . $^{9,10}$

The seminal plasma provides a nutritive and protective medium for the spermatozoa during their journey through the female reproductive tract. ${ }^{11}$ Seminal fluid provides nutrients to the spermatozoa; it is also protective in the hostile environment of the female reproductive tract. $^{6}$ Semen analysis is a very simple, basic and noninvasive laboratory procedure that provides some important information about fertility potential of the male. This information may not be complete but may be useful to give a direction to further investigation.

\section{OBJECTIVES}

To describe the pattern of semen parameters in sub-fertile males

To look into frequency and distribution of abnormal semen parameters in a group of Pakistani males in Lahore

\section{METHODOLOGY}

In this Retrospective, cross sectional, observational study all males undergoing for evaluation and treatment for sub-fertility at a private Assisted Reproductive Technology clinic in Lahore, Pakistan during the study period were included. Approval of the IRB was sought and data collection instrument was a specially designed Performa which was validated by the biostatistician of LIFE research cell. Data was extracted from the files of LIFE (Lahore Institute of Fertility and Endocrinology) and entered in
SPSS version 15. Sampling technique was nonprobability, consecutive. Semen analysis was done by methods defined by the WHO (World Health Organization). Variables included color, volume, liquefaction, viscosity, sperm concentration, sperm motility, rapid progressive motility, slow progressive motility, poor progressive motility, sperm morphology, abnormal sperm morphology, abnormal sperm heads, abnormal neck/mid piece, tail defects. After making table and graphs descriptive analysis was done i.e. frequencies and percentages of categorical variables and mean, standard deviation and standard error for numerical variables.

\section{RESULTS}

Of total patient $(n=679) \quad 92.2 \% \quad(626)$ males passed sample at LIFE (Lahore institute of fertility and endocrinology) and (7.8\%) 53 brought sample from home. Of the males who passed sample at LIFE (78.8\%) 535 collected semen by masturbation, (11.9\%) 81 by coitus; the source of sample of (9.3\%) 63 males was not known. Color of the sample was found to be normal in (99.7\%) 677 patients where as only $(0.3 \%) 2$ had reddish colored semen.

As 2-6 $\mathrm{ml}$ semen was considered to be normal by WHO criteria, (80.6\%) 547 males were in normal range (14.1\%) 96 found to be less than $<2 \mathrm{ml}$ and (5.3\%) 36 found to be more than normal range (>6 ml).

Majority of the male's i.e (99.4\%) 675 had normal liquefaction and in (0.6\%) 4 liquefaction function was not normal. Viscosity was found to be normal in $(97.9 \%) 665$ where as in $(2.1 \%) 14$ viscosity was not normal.

According to WHO criteria 15 million $/ \mathrm{ml}$ count is said to be normal, in our research (82.0\%) 557 males were found to be normal, in $(2.9 \%) 20$ males count was found to be less than 15 million/ $\mathrm{ml}$ and in (5.9\%) 40 patients, count was less than $1 \mathrm{million} / \mathrm{ml}$. In (9.1\%) 62 males count was found to be abnormally low (Fig-1).

According to WHO criteria $40 \%$ motility is said 
to be normal, in our research (66.1\%) 449 males had normal sperm motility, (21.8\%) 148 males had less than $40 \%$ and abnormally low sperm motility was found in (12.1\%) 82 males(Fig-2). Rapid progressive motility was found to be normal in (5.6\%) 38 males, less than $20 \mathrm{mic} /$ second in (66.4\%) 451 and in (28.0\%) 190 males rapid progressive motility was necrosopic (Fig-3). Slow progressive motility was normal in (13.3\%) 90 males, less than 5-20 mic/second in (3.4\%) 23, more than 5-20 mic/second in (68.6\%) 466 and in (28.0\%) 190 males Slow Progressive Motility was azoospermic (Fig-4). In (7.2\%) 49 males poor progressive motility was normal, more than $5 \mathrm{mic} /$ second in (80.9\%) 549 and in (11.9\%) 81 males Poor Progressive Motility was necrospermic (Fig$5)$.

(81.6\%) 554 males had normal sperm morphology, $(9.3 \%) 63$ males had less than $4 \%$ morphology and $(9.1 \%) 62$ males had abnormal morphology (Fig-6). The mean and S.D of abnormal sperm morphology was $(56.57 \pm 0.959,24.99)$, Abnormal sperm heads $(20.35 \pm 0.509,13.275)$, Abnormal neck/mid piece $(13.88 \pm 0.344,8.975)$ and Tail defects $(22.29 \pm 0.458,11.929)$ Table-Il.

\begin{tabular}{|l|c|c|c|c|c|}
\hline Semen parameters & WHO 1980 & WHO 1987 & WHO 1992 & WHO 1999 & WHO 2010a \\
\hline Volume $(\mathrm{mL})$ & ---- & $\geq 2$ & $\geq 2$ & $\geq 2$ & 1.5 \\
\hline Sperm count(106/mL) & $20-200$ & $\geq 20$ & $\geq 20$ & $\geq 20$ & 15 \\
\hline Total Sperm count(106) & ---- & $\geq 40$ & $\geq 40$ & $\geq 40$ & 39 \\
\hline Total motility (\%motile) & $\geq 60$ & $\geq 50$ & $\geq 50$ & $\geq 50$ & 40 \\
\hline Progressive motility & $\geq 2 c$ & $\geq 25 \%$ & $\geq 25 \%(G r a d e ~ A)$ & $\geq 25 \%$ (Grade A) & $32 \%(A+B)$ \\
\hline Vitality $(\%$ alive) & ---- & $\geq 50$ & $\geq 75$ & $\geq 75$ & 58 \\
\hline Morphology $(\%$ normal) & 80.5 & $\geq 50$ & $\geq 30 d$ & 140 & 4 \\
\hline Leukocyte count $(106 / \mathrm{mL})$ & $<4.7$ & $<1.0$ & $<1.0$ & $<1.0$ & $<1.0$ \\
\hline
\end{tabular}

Table-I. Standards for Semen Examination as Published in Consecutive World Health Organization Manuals

Table-I. (Permission granted by Dr. Esteves toads his table in this article). WHO has gradually over years lowered the criteria of normal semen Group table of all variables

\begin{tabular}{|c|c|c|c|c|}
\hline Sr. No & Variable & Categories & frequencies & Percentages \\
\hline \multirow{2}{*}{1} & \multirow[t]{2}{*}{ sample produced at } & LIFE (clinic) & 636 & 92.2 \\
\hline & & Home & 53 & 7.8 \\
\hline \multirow{3}{*}{2} & \multirow{3}{*}{ source of sample } & Masturbation & 535 & 78.8 \\
\hline & & Coitus & 81 & 11.9 \\
\hline & & not known & 63 & 9.3 \\
\hline \multirow{3}{*}{3} & \multirow{3}{*}{ Color } & Normal & 677 & 99.7 \\
\hline & & Reddish & 2 & 0.3 \\
\hline & & Reddish Yellowish & 0 & 0 \\
\hline \multirow{3}{*}{4} & \multirow{3}{*}{ Volume } & Less than $2-6 \mathrm{ml}$ & 96 & 14.1 \\
\hline & & 2-6 ml (normal) & 547 & 80.6 \\
\hline & & More than 2-6 ml & 36 & 5.3 \\
\hline \multirow{2}{*}{5} & \multirow[t]{2}{*}{ Liquefaction } & 30-60 mints (normal) & 675 & 99.4 \\
\hline & & Abnormal & 4 & 0.6 \\
\hline \multirow{2}{*}{6} & \multirow[t]{2}{*}{ Viscosity } & Normal & 665 & 97.9 \\
\hline & & Abnormal & 14 & 2.1 \\
\hline \multirow{4}{*}{7} & \multirow{4}{*}{ sperm concentration } & $15 \mathrm{mil} / \mathrm{ml}$ or more (normal) & 557 & 82.0 \\
\hline & & less than $15 \mathrm{mill} / \mathrm{ml}$ & 20 & 2.9 \\
\hline & & less than $1 \mathrm{mil} / \mathrm{ml}$ & 40 & 5.9 \\
\hline & & Azoospermia & 62 & 9.1 \\
\hline \multirow{3}{*}{8} & \multirow{3}{*}{ Sperm Motility } & $40 \%$ or more (normal) & 449 & 66.1 \\
\hline & & less than $40 \%$ & 148 & 21.8 \\
\hline & & Necrospermia & 82 & 12.1 \\
\hline
\end{tabular}




\begin{tabular}{|c|c|c|c|c|}
\hline Sr. No & Variable & Categories & Frequencies & Percentages \\
\hline \multirow{3}{*}{9} & \multirow{3}{*}{ Rapid progressive Motility } & less than 20 & 451 & 66.4 \\
\hline & & $>20 \mathrm{mic} / \mathrm{second}$ & 38 & 5.6 \\
\hline & & Nil & 190 & 28.0 \\
\hline \multirow{4}{*}{10} & \multirow{4}{*}{ Slow progressive Motility } & Less than $5-20 \mathrm{mic} / \mathrm{sec}$ & 23 & 3.4 \\
\hline & & 5-20 mic/sec (normal) & 90 & 13.3 \\
\hline & & More than $5-20 \mathrm{mic} / \mathrm{sec}$ & 466 & 68.6 \\
\hline & & Nil & 100 & 14.7 \\
\hline \multirow{3}{*}{11} & \multirow{3}{*}{ Poor progressive Motility } & $<5 \mathrm{mic} / \mathrm{sec}$ & 49 & 7.2 \\
\hline & & More than 5 & 549 & 80.9 \\
\hline & & Nil & 81 & 11.9 \\
\hline \multirow{3}{*}{12} & \multirow{3}{*}{ Sperm morphology } & $4 \%$ or more (normal) & 554 & 81.6 \\
\hline & & not in range & 63 & 9.3 \\
\hline & & Abnormal & 62 & 9.1 \\
\hline
\end{tabular}

Descriptive characteristics of semen parameter

Analysis of numeric data (table-III) macphological

\begin{tabular}{|c|l|c|c|c|}
\hline Sr. No & \multicolumn{1}{|c|}{ Numeric variables } & Mean & Std. Error of Mean & Std. Deviatior \\
\hline 1. & Abnormal sperm morphology & 56.57 & .959 & 24.995 \\
\hline 2. & Abnormal sperm heads (\%) & 20.35 & .509 & 13.275 \\
\hline 3. & Abnormal neck/mid piece (\%) & 13.88 & .344 & 8.975 \\
\hline 4. & Tail defects (\%) & 22.29 & .458 & 11.929 \\
\hline
\end{tabular}

\section{Morphological characteristics of sperm parameters}

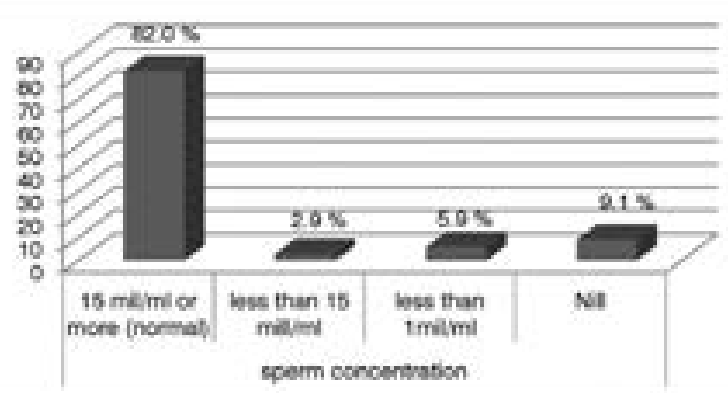

Figure-1. Frequency of sperm concentration

Legend: sperm concentration is shown in four categories and their respective frequency

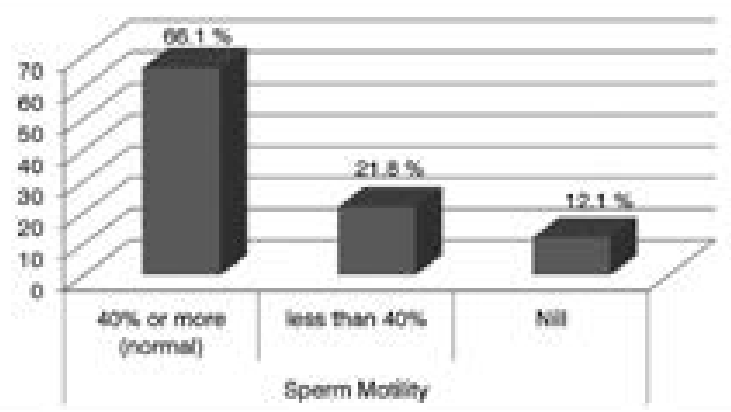

Figure-2. Frequency of sperm Motility

Legend: Sperm Motility is shown in three categories and their respective frequency

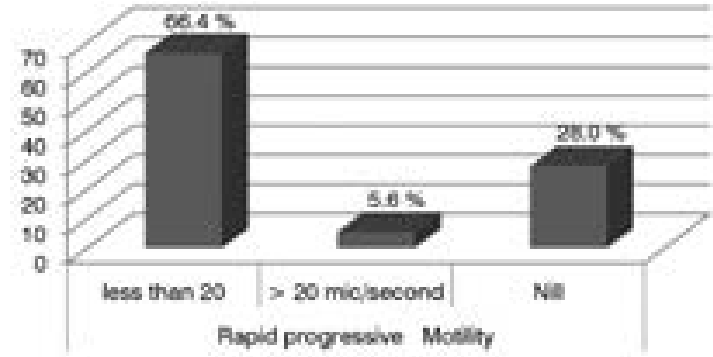

Figure-3. Frequency of sperm Motility Rapid Progressive Motility

Legend: Sperm Rapid Progressive Motility is shown in three categories and their respective frequency

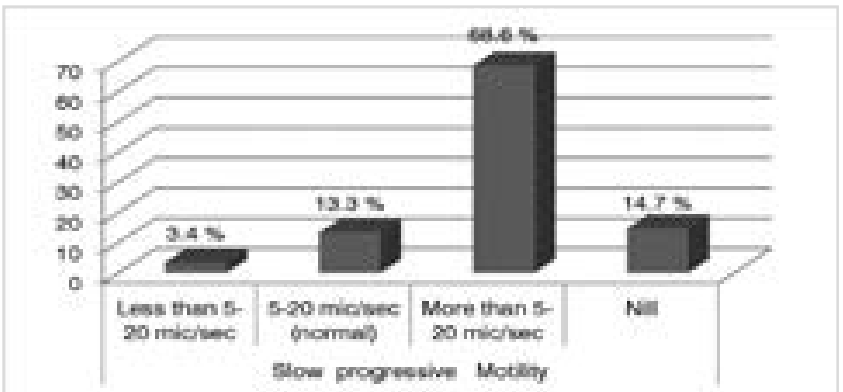

Figure-4. Frequency of sperm Motility Slow Progressive Motility

Legend: Sperm Slow Progressive Motility is shown in four categories and their respective frequency 


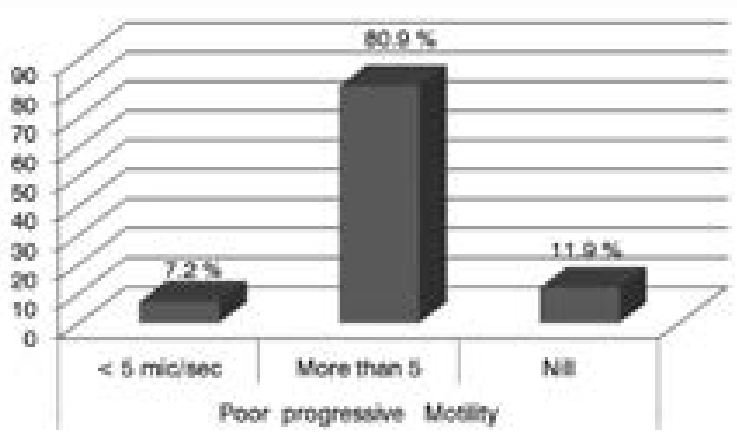

Figure-5. Frequency of sperm Motility poor Progressive Motility

Legend: Sperm poor Progressive Motility is shown in three categories and their respective frequency

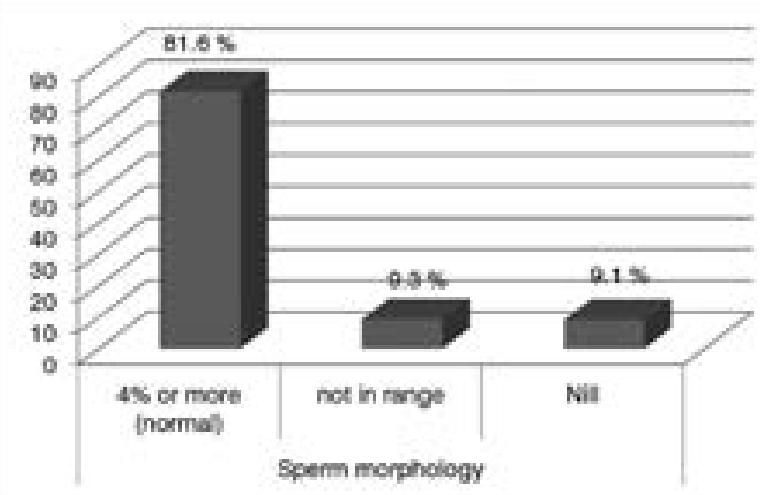

Figure-6. Frequency of sperm Morphology

Legend: Sperm Morphology is shown in three categories and their respective frequency

\section{DISCUSSION}

In this research count was more than 15 million $/ \mathrm{ml}$ in $82 \%(n=679)$, less than 15 million $/ \mathrm{ml}$ in $2.9 \%$, less than one million in $5.9 \%$ and abnormally low count in $9.1 \%$. Motility was more than $40 \%$ in $66.1 \%$ $(n=679)$, less than $40 \%$ in $21.8 \%$ and abnormally low sperm motility in $12.1 \%$. Morphology was more that $4 \%$ in $81.6 \%(n=679)$, less than $4 \%$ in 9.3\% and $9.3 \%$ had abnormal morphology.

Semen analysis has been regarded as a single most important test for male subfertility. ${ }^{12,1,13}$ Semen analysis also furnishes information about functioning of accessory sex glands, epididymis and seminiferous tubules. ${ }^{14-18}$ Despite phenomenal advancement in assisted reproductive technology role of a robust semen analysis is still not diminished. ${ }^{[19]}$ As clinicians use the results of semen analysis in crucial decision making, like diagnosis and treatment, it must be reliable. ${ }^{20}$

Sperm parameters which are normal according WHO criteria may misguide the clinician and a sub-fertile male with "normal" sperm parameters may be misdiagnosed as a case of unexplained subfertility. ${ }^{21}$ Special sperm function tests such as DNA fragmentation, oxidative stress, will help to finalize the diagnosis. ${ }^{22}$

Though standards set by WHO have been accepted by most of the labs performing semen evaluation. Several reports of sub-fertile males will be regarded as normal which were said to be abnormal before. So referral of these sub-fertile males to the fertility center may be delayed for separated semen analysis. ${ }^{23,24}$ It has been also proposed that assessing the sperm parameters like morphology and motility may not be sufficient. ${ }^{25}$ Good practice should include, a thorough history taking and complete clinical examination, followed by relevant endocrine and genetic studies. ${ }^{14}$ Medical evaluation may also be essential in males of higher age group. ${ }^{22}$

Importance of sperm morphology and motility in relation to occurrence of pregnancy in sub fertile couples undergoing ART investigation like IVF/ ICSI was confirmed in a number of studies and the value of sperm concentration was reduced. ${ }^{26}$

Sperm motility is critical at the time of fertilization because as the sperm passes through the ZonaPellucida motility helps and increases the chance of conception. Decreased sperm motility not only reduces the movement of sperm in the cervical mucus but also hampers the transport of sperm towards the egg. ${ }^{27,28,29}$

Sperm concentration is associated with fecundity. Sperm count less than $20 \times 10^{6} / \mathrm{mL}$ has been associated with reduced fecundity. ${ }^{30}$

It was found that all the sperm factors do not have equal significance in predicting male fertility potential in couples with higher the percentage 
of motile sperms with normal morphology, pregnancy rate was significantly higher. ${ }^{31}$

In a study SandroEsteves compared cut off references value of characteristics of semen which were published in various WHO manuals in between 1980-2010. This table (table-l) shows semen characteristics which were labeled as normal by $\mathrm{WHO}$ in various manuals. ${ }^{14}$

Anne Jequier suggested three decades ago that quality assurance in the laboratories performing semen analysis was necessary. ${ }^{32}$ About ten years ago she proposed that quality assurance was no more needed for laboratories performing semen analysis. The notion behind this statement was the results of research in the last three decades which proved that though semen analysis was very important investigation to start the evaluation of male subfertility but was not sufficient to make a final diagnosis. Even sperm functions tests had little prognostic value in terms of fertility assessment ${ }^{33}$ Jequier concluded that a competently performed semen analysis was sufficient and there was no need of the expense, time and effort being wasted in the quality assurance ${ }^{.34}$

Duration of abstinence, individual biological variability and activities of accessory glands and error of analysis are, to some extent responsible, for high variability of semen characteristics from same individuals. ${ }^{35,14}$ It adds to the uncertainty about the semen analysis results and their clinical importance. The results of the single semen analysis are of limited utility and no decision should be taken on the bases of these results in term of diagnosis and treatment strategies. ${ }^{14}$

\section{CONCLUSION}

The results of the single semen analysis are of limited utility and no decision should be taken on the bases of these results in term of diagnosis and treatment strategies. Semen analysis still remains an important investigation regarding male sub fertility. A complete history and thorough clinical examination is essential to reach final diagnosis. Copyright@ 29 March, 2016.

\section{REFERENCES}

1. Vasan SS. Semen analysis and sperm function tests: How much to test? Indian J Urol. 2011; 27(1):41-8.

2. Carrell DT. Semen analysis at the turn of the century: an evaluation of potential uses of new sperm function assays. Arch Androl. 2000; 44(1):65-75.

3. Khan MS, Irshad A, Zulfaqar KA, Faheem T, Subhan R, Deepa F, Alam W, Kazi BM, Karamat KA. Pattern of semen characteristics in infertile males. Gomal $\mathrm{J}$ Med Sci 2005; 3: 6-9.

4. Rehan N. Semen characteristics of fertile Pakistani men. J Pak Med Assoc. 1994; 44(3):62-4.

5. Moazzam A, Choudhary MN, I. Muhammad I, Sarwat $J$ and ljaz A From basic to contemporary semen analysis: limitations and variability. J. Anim. Plant Sci. 2015; 25(2) 328-336.

6. Butt F, Akram N. Semen analysis parameters: experiences and insight into male infertility at a tertiary care hospital in Punjab. J Pak Med Assoc. 2013; 63(5):558-62.

7. Barack BM. Transport of spermatozoa from seminiferous tubules to epididymis in the mouse: a histological and quantitative study. J ReprodFertil.1968; 16(1):35-48.

8. Harper MJK Gamete and zygote transport. In Nobil E and Neill JD (eds), The Physiology of Reproduction, 2nd edn. Raven Press Ltd., NewYork, NY, 1994 pp. 123187.

9. Wilcox AJ, Weinberg CR, Baird DD. Timing of sexual intercourse in relation to ovulation. Effects on the probability of conception, survival of the pregnancy, and sex of the baby. N Engl J Med.1995; 333(23):151721.

10. Suarez SS, Pacey AA. Sperm transport in the female reproductive tract. Hum Reprod Update.2006; 12(1):23-37.

11. Austin CR Fate of spermatozoa in the uterus of the mouse and rat. J Endocrinol.1957; 14,335-342.

12. Khan MS, Deepa F, Ahmed Z, Tahir F, Khan MA. Assessment of male reproductive health by conventional method of semen analysis. J Ayub MedColl Abbottabad. 2011; 23(1):84-8.

13. EllekildeBonde JP. Semen analysis from an epidemiologic perspective. Asian J Androl. 2010; 12 (1):91-4.

14. Esteves SC. Clinical relevance of routine semen 
analysis and controversies surrounding the 2010 World Health Organization criteria for semen examination. IntBraz J Urol. 2014 Dec 3.

15. World Health Organization. Cambridge; Cambridge University Press 1987. World Health Organization Laboratory Manual for the Examination of Human Semen and Semen-Cervical Mucus Interaction. 2nd ed.

16. World Health Organization. Cambridge; Cambridge University Press; 1992. World Health Organization Laboratory Manual for the Examination of Human Semen and Semen-Cervical Mucus Interaction. 3rd ed.

17. World Health Organization. Cambridge; Cambridge University Press; 1999. WHO Laboratory Manual for Examination of Human Semen and Semen-Cervical Mucus Interaction. 4th ed.

18. World Health Organization. Geneva; (2010) World Health Organization;. WHO Laboratory Manual for the Examination and Processing of Human Semen. 5th ed.

19. Barratt CL. Semen analysis is the cornerstone of investigation for male infertility. Practitioner. 2007;251(1690):8-10, 12, 15-7.

20. McLachlan RI, Baker HW, Clarke GN, Harrison KL, Matson PL, Holden CA, de Kretser DM; Andrology Australia Australian Centre of Excellence in Male Reproductive Health; Fertility Society of Australia Scientists in Reproductive Technology Subcommittee; Board of Education of the Royal College of Pathologists of Australia. Semen analysis: its place in modern reproductive medical practice. Pathology. 2003; 35(1):25-33.

21. Wong WY, Thomas CM, Merkus JM, Zielhuis GA, Steegers-Theunissen RP. Male factor subfertility: possible causes and the impact of nutritional factors. FertilSteril. 2000; 73(3):435-42.

22. Esteves SC, Miyaoka R, Agarwal A. An update on the clinical assessment of the infertile male. [corrected]. Clinics (Sao Paulo). 2011; 66(4):691-700. Review. Erratum in: Clinics (Sao Paulo). 2012; 67(2):203.

23. Murray KS, James A, McGeady JB, Reed ML, Kuang WW, Nangia AK. The effect of the new 2010 World Health Organization criteria for semen analyses on male infertility. FertilSteril. 2012; 98(6):1428-31.
24. Centola GM. Determination of male infertility: is the 2010 WHO reference range helpful or confusing? FertilSteril. 2012; 98(6):1416-7.

25. Ismail A, Nasr A. Semen analysis: Indispensable, yet non-ideal. Middle East FertilSoc J. 2013 18(4) 287-288.

26. Ducot B, Spira A, Feneux D, Jouannet P. Male factors and the likelihood of pregnancy in infertile couples. II. Study of clinical characteristics-practical consequences. Int J Androl. 1988 (5):395-404.

27. 28Guzick DS, Overstreet JW, Factor-Litvak P. Sperm morphology, motility, and concentration in fertile and infertile men. N Engl J Med; 2001; 345: 1388-93.

28. Guyton AC, Hall JE. Text book of medical physiology. 11th ed. 2006 Philadelphia: W.B. Saunders.

29. Ahmad MO, Hameed MA, Ashraf N, Siddiq AA and Khan UA. A comparison of sperm motility between fertile and infertile males. J Rawalpindi Med Col. 2008; 12(2): 12-15.

30. Slama R, Eustache F, Ducot B, Jensen TK, Jørgensen $\mathrm{N}$, Horte A, Irvine S, Suominen J, Andersen AG, Auger J, Vierula M, Toppari J, Andersen AN, Keiding N, Skakkebaek NE, Spira A, Jouannet P. Time to pregnancy and semen parameters: across-sectional study among fertile couples from four European cities. Hum Reprod. 2002; Feb; 17(2):503-15.

31. Jouannet P, Ducot B, Feneux D, Spira A. Male factors and the likelihood of pregnancy in infertile couples. I. Study of sperm characteristics. Int J Androl. 1988; 11(5):379-94 .

32. Jequier $A M$. Is quality assurance in semen analysis still really necessary? A clinician's viewpoint. Hum Reprod. 2005; 20:2039-2042.

33. Jequier AM. Semen analysis: a new manual and its application to the understanding of semen and its pathology. . Asian J Androl. 2010; 12:11-13.

34. Holt WV. Is quality assurance in semen analysis still really necessary? A spermatologist's viewpoint. Hum Reprod. 2005; 20(11):2983-6.

35. Levitas E, Lunenfeld E, Weiss N, Friger M, Har-Vardi I, Koifman A, Potashnik G. Relationship between the duration of sexual abstinence and semen quality: analysis of $\mathbf{9 , 4 8 9}$ semen samples. FertilSteril. 2005; 83(6):1680-6. 


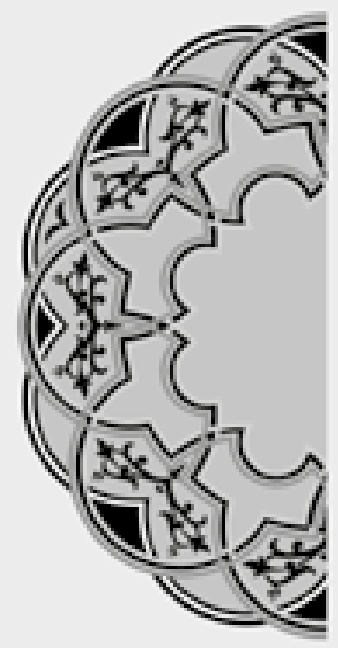

\section{"Price is what you pay. Value is what you get."}

\section{WARREN BUFFETT}

\begin{tabular}{|c|c|c|c|}
\hline \multicolumn{4}{|c|}{ AUTHORSHIP AND CONTRIBUTION DECLARATION } \\
\hline Sr. \# & Author-s Full Name & Contribution to the paper & Author $=$ s Signature \\
\hline 1 & Dr. Haroon Latif Khan & $\begin{array}{l}\text { Main resource person } \\
\text { conducted the procedure } \\
\text { and generate the data } \\
\text { Conceptualization and } \\
\text { designing the study } \\
\text { and helped in writing } \\
\text { introduction }\end{array}$ & \\
\hline 3 & & Helped in data collection & \\
\hline 4 & Muhammad Burhan & $\begin{array}{l}\text { coordination and eiterative } \\
\text { search }\end{array}$ & \\
\hline 5 & Saba Sardar & $\begin{array}{l}\text { Data analysis and } \\
\text { interpretation of the results }\end{array}$ & \\
\hline 6 & Dr. Abdul Rahman Khawaja & $\begin{array}{l}\text { Write up of eiterative review } \\
\text { discussion and concusion }\end{array}$ & \\
\hline
\end{tabular}

